\title{
The Significance of Comparative Advantage Theory and Competitive Advantage Theory to the Development of China's Foreign Trade
}

\author{
Zhili Ren ${ }^{1}$, Yuwei $\mathrm{Ma}^{2}$ \\ ${ }^{1}$ Shaanxi Normal University International Business School in Xi'an, China \\ ${ }^{2}$ Shaanxi Normal University International Business School in Xi'an, China
}

\begin{abstract}
For a long time, China's foreign trade has remained dominated by labor-intensive products. The international division of labor, which only takes comparative advantages, cannot fundamentally drive the country's economic development, but will cause China fall into the "trap of comparative advantage". Based on the study and analysis of the influence of comparative advantage theory and competitive advantage theory on China's foreign trade, this paper concludes that China must adjust its trade development strategy and change from comparative advantage strategy to competitive advantage strategy under the guidance of competitive advantage theory.
\end{abstract}

Keywords-Comparative Advantage; Competitive advantage; Comparative Advantage Trap; The Ministry of Foreign Trade

\section{INTRODUCTION}

In the process of world economic globalization, foreign trade plays an important role and has become one of the driving forces for a country's economy to enter the world economic cycle and drive its citizens' economic growth. As a major developing country, China has made great achievements in adopting a development strategy of comparative advantage in carrying out foreign trade. However, with the expansion of the scale of foreign trade and the changes in the international and domestic situations, the simple strategy of comparative advantage presents a phenomenon of inadaptability. The economic effects of big countries limit the display of comparative advantage. When China's trade is large in scale, the difficulty of export expansion increases.

Therefore, in order to gain benefits in international trade, the comparative advantages of domestic products must be transformed into competitive advantages. Comparative advantage emphasizes more on the potential possibility of advantage, while competitive advantage emphasizes more on the actual situation of advantage. Products with comparative advantages do not necessarily have competitive advantages. The trade form determined by comparative advantages does not necessarily transform into the actual trade form. Only after the comparative advantage product is transformed into competitive advantage product can the transformation be completed.

\section{BRIFS INTRODUCTION OF THE THEORY OF COMPARATIVE ADVANTAGE AND THE THEORY OF COMPETITIVE ADVANTAGE}

\section{A. The Theory of Comparative Advantage}

Adam Smith set forth the famous "invisible hand" mechanism in the wealth of nations, arguing that "free trade leads to international division of labor based on favorable natural endowment or favorable production conditions. All of them can put a country in a better position than others in terms of production and foreign trade. The most effective use of the resources, labor and capital of each country will be achieved if all countries divide their labor and exchange in accordance with their favorable production conditions, which will greatly increase labor productivity and material wealth."

David Ricardo thinks: even if a country does not have any absolute advantage, but as long as the country's production in the country the opportunity cost of a product is lower than in other countries the opportunity cost of production of this kind of product, is the country has a comparative advantage in the production of this kind of product, if every country exports its products with comparative advantages, the trade between the two countries can benefit both countries. That is to say, countries with absolute advantages in the production of various products should concentrate resources to produce products with larger advantages, while countries with disadvantages should concentrate resources to produce products with smaller disadvantages.

\section{B. The Theory of Competitive Advantage}

Porter put forward the famous theory of competitive advantage in his published competitive strategy (1980), competitive advantage (1985) and national competitive advantage (1990).Porter believes that the competitive advantage of a country is the competitive advantage of enterprises and industries, which is also the advantage of the development level of productivity. He believes that the fundamental reason for the rise and fall of a country lies in whether it can obtain competitive advantage in the international market. The key to the formation of competitive advantage lies in whether the leading industry can have advantages. The establishment of superior industry depends on the improvement 
of productivity. He also believes that in today's world where global competition is intensifying, countries are becoming more and more important. As the basis of competition turns to creating and absorbing knowledge, national competitive advantage is generated and maintained through a highly localized process.

From a macro perspective, the key to a country's global success in an industry lies in four basic elements, namely, factors of production, demand situation, related and supporting industries, and enterprise strategy, structure and competition. Together with two supporting factors (opportunity and the role of government), it determines whether a country creates an environment conducive to competitive advantage. Based on four elements and two auxiliary aspects, porter proposed the "diamond model of national competitive advantage".

\section{THE SignIFICANCE OF COMPARATIVE ADVANTAGE THEORY AND COMPETITIVE ADVANTAGE THEORY TO THE DEVELOPMENT OF CHINA'S FOREIGN TRADE}

\section{A. The Significance of Comparative Advantage Theory to the Development of China's Foreign Trade}

Labor advantage has always been China's foreign trade development and an important foundation for realization of comparative advantage, the great powers of China as a developing country, since China's reform and opening up, we take advantage of labor resources, development of processing trade, to undertake the world order, production and exports a large number of labor-intensive products, to meet market demand abroad at the same time, greatly increased the international income and also boost the rapid development of the domestic economy. It is in this sense that the advantage of labor resources has played an important supporting role in the development of China's national economy in the past 30 years of reform and opening-up, especially the transformation and realization of China's comparative advantage in foreign trade.

Judging from the composition and endowment of factors, capital, land, raw materials, labor and other factors of production, such as capital, land, raw materials, and other factors of production, are mutually substituted for each other in use, while labor, which is not, has complementary nature in the production process, and thus is a very important factor of production. The quantity level of labor input directly influences the scale of production, while the quality of labor input influences and determines the efficiency of production labor. In particular, China currently has a very intensive labor factor, which is an important source of driving force for China's economic development and national wealth creation. Of course, it should also be a driving force for China's foreign trade to achieve sound and rapid development.

Especially for China's textile products, the low labor cost is the biggest comparative advantage of China's textile industry, which also makes China a veritable "textile power". Every year, China has to produce large-scale textiles and sell them all over the world. In recent years, the RCA value of Chinese textiles is above 2.6, and it shows a trend of increasing year by year, which indicates that Chinese textiles are in a favorable position in international trade. According to China's total import and export of goods is not hard to find in recent years, China's trade exports presents the increasing trend year by year, which makes the status of China in the international trade is more important, a more powerful position in the international market and the increase of trade exports largely thanks to the textile industry, the labor-intensive industries, because of its exports accounted for the proportion of all exports of goods in China, the textile industry to the development of China's foreign trade has played a vital role, which reflects the comparative advantage theory conforms to the needs of the comparative advantage of Chinese labor force, has a strong practical significance to the development of China's foreign trade.

\section{B. The Significance of Competitive Advantage Theory to the Development of China's Foreign Trade}

However, the reality of the development of international trade shows that the comparative advantage strategy cannot change the face of economic backwardness of developing countries, nor can it change the unfair phenomenon in the distribution of international trade benefits. The strategy of comparative advantage overemphasizes the static trade benefits and ignores the dynamic trade benefits, that is, the role of foreign trade in promoting the evolution of industrial structure, technological progress and institutional innovation. Long-term perform a simple comparative advantage strategy can lead to a country's industrial structure cannot be upgraded, and have the function of the curing the original industrial division, the disadvantage in the international division of labor, in developing countries, in turn, may worsen the developing countries in terms of trade and the phenomenon of immiserizing growth, namely the comparative advantage trap. As far as China's rare earth exports are concerned, it falls into the trap of comparative advantage. China's rare earth reserves of the world's total first, in 1996 China's rare earth reserves account for the proportion of $43 \%$, with natural endowment advantage, but because of the blind development, a large number of low-priced exports, not only makes China's rare earth reserves account for global proportion fell to $30 \%$, and only received relatively low value-added, coupled with the low price, a resource consumption considerably, the environment pollution, make China at a very disadvantage in rare earth export aspect, thus in the comparative advantage trap. Therefore, many scholars think that the theory of competitive advantage is more in line with the development of today's international trade than the theory of comparative advantage.

After the reform and opening up, the province of Guangdong, as the earliest special economic zone and the frontier of reform and opening up, has achieved rapid development of foreign economic and trade. In 1978, the export trade volume of the province of Guangdong was only 13.876 billion us dollars. By 1986, the export volume had reached 42.8216 billion us dollars. Most of the commodities exported by the province of Guangdong are no longer laborintensive products with low added value, but products with international competitiveness such as mechanical and electrical products and high-tech products. In recent years, the proportion of mechanical and electrical products exported by the province of Guangdong has exceeded $60 \%$, and the proportion of hightech products exported has been close to $40 \%$. 
We know that the source of international trade interests is the comparative advantage based on low cost and the competitive advantage derived from core competitiveness and brand effect. From the perspective of the trade pattern of the province of Guangdong, it take full advantage of the export of mechanical and electrical products and high-tech products to develop their own trade, constantly makes your product is competitive in the international market, with core competitiveness in science and technology innovation and production products of the province of Guangdong investment has large scale, the exports of high-tech products appear the phenomenon of increasing year by year, and increase obviously. This shows that the province of Guangdong, as the most rapid development of China's foreign trade, no longer relies solely on China's comparative advantages of low labor cost and natural endowment to develop foreign trade, but actively uses the national competitive advantage strategy to constantly improve the international competitiveness of export products and vigorously develop technology-intensive industries.

\section{CONCLUSIONS}

We have been making use of China's comparative advantage of low labor cost to develop foreign trade, making us a world recognized major country of textile, and the achievements we have made are undeniable. But we also want to see with the improvement of living standards, the worker's wages have larger growth in China, the labor cost is in constant increase, moreover this kind of labor-intensive products have no competitiveness in the international market, the added value is low, which makes if we blindly follow the comparative advantage theory development trade, they will not develop long-term health.

Again in the province of Guangdong rapid foreign trade development, as well as to the leading role and supporting role of China's foreign trade, it is not difficult to find in today's international trade of technology-intensive products, core competitiveness and brand effect to the benefits of a country's trade is how large, sustained and healthy development for a country's trade has played a very important role. Therefore, it is necessary to implement the national competitive advantage strategy to improve the competitiveness of China's foreign trade.

\section{A. Break away from the comparative advantage trap and cultivate advanced production factors}

China should take advantage of the large number of opportunities for multinational companies to invest in China and combine the use of foreign capital with the adjustment and optimization of industrial structure. In the value chain of China's processing trade has been in a low technical content and profit thin, so the culture elements of advanced technology in processing trade also not allow to ignore, the processing trade of the industrial structure changes should follow the world within the scope of the industrial structure adjustment, by export processing general industrial goods to export processing, high technology content, high value-added products, from production outsourcing to tech outsourcing shift can make China's processing trade scale from simple labor resource advantage to technology resources advantage.

\section{B. Appropriately ease imports and stimulate domestic demand}

Domestic demand is a long-term driver of China's economic growth. Relaxing import restrictions can not only improve the imbalance between China and world trade and reduce trade surplus, but also change the growth mode of China's foreign trade by changing the demand structure of Chinese residents. Especially under the impact of the current international financial crisis, using the domestic market to expand domestic demand is one of the ways to "get out" of the global economic crisis. By increasing the import of consumer goods, the types and quantities of consumer goods available to domestic residents will be increased, the quality and grade of domestic products will be improved, living standards will be improved, and welfare will be increased, thus changing the consumption choices and behaviors of residents.

\section{Form brand industry and extend industrial chain}

China's international division of labor is at the bottom end of the "smile curve" in the industrial chain, and the left end and the right end respectively include R\&D and design, transportation and storage, logistics and distribution, marketing and after-sales service. For a country, the more processing links in the country, the longer the industrial chain, the higher the domestic value-added rate, the more favorable to the national economy. Most of China's processing trade is in the development stage of "one in one out, single process". There is a general lack of leading enterprises and supporting cooperative enterprises with strong driving force. In fact, some low-skilled labor-intensive industries in China have trained a large number of skilled workers in the processing trade, mastered the production management technology and developed economies of scale. As long as they have their own designed products, they can make and operate by themselves, such as the garment industry. At this time, what should be done is to get rid of the extensive processing and manufacturing of OEM production, and use the raw materials and parts of China to refine the products, improve product quality, increase product categories, increase the intensity of marketing links, establish their own industrial chain, give play to their national characteristics, and develop their own brand.

\section{Increase government policy input and propse function transformation}

China should increase policy input in modern technological innovation. Modern technology innovation is the guarantee system of high investment under the condition of the conscious, the U.S. government as a world trade power, size of R\&D is very large, research and development of the United States remains the world's largest investor, although China R\&D cost is also on the increase year by year in recent years, but whether it is from absolute quantity and relative quantity are there is a huge gap with the United States, this shows China's technological gap with the United States can be attributed in part to R\&D. We should make full use of the human resources of universities and combine the research and development of universities closely with the technological innovation of enterprises so as to shorten the time difference between the theory and productivity. Industries with strong economic and 
technological strength and comparative advantages should be provided with necessary preferential policies, and the construction of supporting facilities should be strengthened to make these industries become leading industries with international competitiveness and support domestic economy.

In short, in the deepening of economic globalization, the competition is fierce today, in order to adapt to the change of the international economic situation, adapt the knowledge economy and the needs of the development of high and new technology industry booming, both to seize new opportunities, and to meet new challenges, competitive advantage theory as the guide, actively foster the international competitiveness of China's total trade, adjust the structure of their country's trade industry international competitiveness, so as to promote China's foreign trade development strategy shift from comparative advantage to competitive advantage, and further adjusting and perfecting the relevant foreign trade system and policy design, to adapt to the international competitiveness of domestic trade goods defense requirements. Striving is the country's competitive advantage can develop to a higher stage.

\section{REFERENCES}

[1] Yushan Ji. Transcending the comparative advantage trap [J]. Learning and exploration, 2010. (In Chinese)

[2] Jiguo Zhang, Juan zhou. From comparative advantage to competitive advantage. Business studies, 2007. (In Chinese)

[3] Xiu Zhang, Jianjun Sun. Trade strategy selection based on comparative advantage and competitive advantage [J].2007. (In Chinese)

[4] Xiaochen Zhao. Development of dynamic comparative advantage theory in practice [J] economic longitude and latitude, 2007. (In Chinese)

[5] Jianguo Huo. China's foreign trade and national competitive advantage [M]. Beijing: China business press, 2007. (In Chinese)

[6] Rongjiu Xue. Looking at China's manufacturing industry from porter's national competitive advantage [J]. International economic cooperation, 2007. (In Chinese)

[7] Tao Wan. Study on China's competitive advantage in foreign trade [M].Beijing: China financial and economic publishing house, 2007. (In Chinese)

[8] Rongjiu Xue. International trade [M]. Beijing: university of international business and economics press, 2009. (In Chinese)

[9] Lihua Dai. Analysis and countermeasures of China's foreign trade [J]. Popular commerce, 2009. (In Chinese)

[10] Taoxiong Liu. Can we avoid the "comparative advantage trap"? [J] macroeconomic research, 2012. (In Chinese) 